\title{
Kajian Efisiensi Bank Umum Syariah di Indonesia
}

\author{
Efficiency of Islamic Bank in Indonesia
}

\author{
Siti Karimah ${ }^{1}$, Tanti Novianti ${ }^{2}$, Jaenal Effendi ${ }^{3}$ \\ ${ }^{1}$ Alumnus Program Studi Ilmu Ekonomi Syariah, Institut Pertanian Bogor, Email sitikarimah26@gmail.com \\ ${ }^{2}$ Dosen Program Studi Ekonomi Studi Pembangunan, Institut Pertanian Bogor, Email \\ tantinovianti@yahoo.com \\ ${ }^{3}$ Dosen Program Studi Ilmu Ekonomi Syariah, Institut Pertanian Bogor, Email jaenfendi@googlemail.com
}

\begin{abstract}
The aim of this study is to measure the efficiency of Islamic Bank in Indonesia and to analyze the factors that affect the level of efficiency. The objects of this study are ten Islamic Bank (BUS) in Indonesia which analyzes from the second quarter of 2012 until the first quarter of 2016. There are three method which are used in this study, two in first stage, namely non parametric method of Data Envelopment Analysis (DEA) and parametric method of Stochastic Frontier Approach (SFA) then the second stage is Tobit estimaton. Overall, the results showed that the efficiency level of Islamic banks in Indonesia during the time period in this study have not reached the optimum level of efficiency yet. Tobit estimation showed that total financing, total wadiah funds, CAR, ROE, total overhead cost significantly affect the Islamic bank's efficiency in Indonesia.
\end{abstract}

Keywords: Banking, DEA, efficiency, SFA, Tobit

\begin{abstract}
Abstrak. Penelitian ini bertujuan mengestimasi efisiensi Bank Umum Syariah di Indonesia dan menganalisis faktor-faktor yang memengaruhinya. Objek penelitian ini terdiri dari sepuluh Bank Umum Syariah di Indonesia periode kuartal kedua tahun 2012 - kuartal pertama tahun 2016. Terdapat dua tahap yang dilakukan pada penelitian ini, pertama, estimasi skor efisiensi dengan metode parametrik, Data Envelopment Analysis (DEA) dan metode non-parametrik, Stochastic Frontier Approach (SFA). Kedua, analisis faktor-faktor yang memengaruhi skor efisiensi dengan estimasi Tobit. Hasil penelitian menunjukkan bahwa secara umum Bank Umum Syariah di Indonesia belum beroperasi secara efisien. Hasil estimasi Tobit menunjukkan total pembiayaan, dana simpanan wadiah, CAR, ROE, dan biaya operasional lainnya berpengaruh secara signifikan terhadap efisiensi Bank Umum Syariah di Indonesia.
\end{abstract}

Kata kunci: $B U S, D E A$, efisiensi, SFA, Tobit

\section{Pendahuluan}

Bank syariah mulai berkembang di dunia sejak bank syariah modern pertama, Mit Ghamr Bank, didirikan di Mesir pada tahun 1960-an (Husein et al. 2015). Awalnya bank syariah didirikan untuk memenuhi kebutuhan muslim di negara dengan mayoritas penduduk beragama Islam (Mokhtar et al. 2006). Setelah itu negara lainnya mulai mendirikan bank syariah untuk memenuhi banyaknya permintaan penduduk dunia terhadap produk-produk keuangan syariah seperti pembiayaan syariah (Kablan dan Yousfi 2013).

Kesuksesan perkembangan perbankan syariah tidak hanya terjadi di negara dengan mayoritas penduduk beragama Islam, tetapi juga di negara dengan mayoritas penduduk beragama non-Islam seperti Amerika dan Inggris (Irfan et al. 2014). Perbankan syariah dikenal sebagai industri yang memiliki tingkat pertumbuhan tertinggi di industri keuangan serta penyebarannya terjadi di seluruh dunia khususnya di negara Timur Tengah dan Asia Tenggara (Rahman dan Rosman 2013) termasuk di Indonesia.

Indonesia memberlakukan dual banking system sejak tahun 1992 melalui UU No 7 Tahun 1992. Bank Muamalat Indonesia (BMI) merupakan bank syariah pertama yang berdiri di Indonesia disusul oleh Bank Syariah Mandiri (BSM) dan bank syariah lainnya hingga jumlah Bank Umum Syariah Jurnal Al-Muzara'ah Vol.4, No.1, 2016 
(BUS) di Indonesia pada Juni 2016 berjumlah 12 bank. Perkembangan bank syariah juga mendapat dukungan dari pemerintah melalui UU No.21 tahun 2008 tentang perbankan syariah. UU tersebut menyatakan bahwa Bank Umum Syariah adalah bank yang menjalankan kegiatan usahanya berdasarkan prinsip syariah.

Tabel 1 Indikator perkembangan Bank Umum Syariah periode 2011-2016

\begin{tabular}{lrrrrrr}
\hline \multirow{2}{*}{ Indikator } & \multicolumn{7}{c}{ Tahun } \\
\cline { 2 - 7 } & \multicolumn{1}{c}{2011} & \multicolumn{1}{c}{2012} & \multicolumn{1}{c}{2014} & \multicolumn{1}{c}{2015} & \multicolumn{1}{c}{$2016^{*}$} \\
\hline Jumlah BUS & 11 & 11 & 11 & 12 & 12 & 12 \\
Jumlah kantor & 1401 & 1745 & 1998 & 2163 & 1990 & 1869 \\
Jumlah tenaga kerja & 21820 & 2411 & 26717 & 41393 & 51413 & 50287 \\
Aset & 116930 & 147581 & 180360 & 204961 & 213423 & 212298 \\
DPK & 115415 & 147512 & 183534 & 215339 & 231820 & 233808 \\
Pembiayaan & 102655 & 147505 & 184833 & 218429 & 235544 & 238742 \\
\hline
\end{tabular}

Keterangan: *April 2016

Sumber: Bank Indonesia (2016,diolah)

Tabel 1 menunjukkan bahwa BUS mengalami perkembangan yang cukup pesat pada industri perbankan di Indonesia. Hal ini ditandai dengan pertumbuhan total sejumlah indikator yaitu jumlah BUS, jumlah kantor, jumlah tenaga kerja, aset, Dana Pihak Ketiga (DPK), dan total pembiayaan. Pertumbuhan ini menandakan bahwa BUS dapat diterima dengan baik oleh masyarakat sehingga usahanya dapat terus berjalan dan berkembang.

Pesatnya perkembangan industri perbankan di Indonesia membuat pengukuran mengenai efisiensi perbankan syariah menjadi penting. Dengan mengetahui tingkat efisiensi bank syariah, akan diketahui seberapa besar kemampuan bank syariah dalam mengoptimalkan seluruh sumber daya yang dimilikinya. Implikasinya bank akan dapat memberikan manfaat yang lebih besar kepada masyarakat. Hal ini diperkuat oleh Mohamad et al. (2009) yang menyatakan bahwa jika bank memiliki kinerja yang efisien, tingkat keuntungan akan meningkat, bank akan mampu menyalurkan lebih banyak dana, bank dapat menawarkan tingkat harga, kualitas jasa, keamanaan yang lebih baik serta meningkatkan kesejahteraan ekonomi secara menyeluruh.

Terdapat beberapa pendekatan yang dapat digunakan untuk menganalisis kinerja efisiensi bank, salah satunya adalah pendekatan intermediasi. Rahman dan Rosman (2013) menyatakan bahwa pendekatan intermediasi merupakan pendekatan yang paling baik untuk mengevaluasi kinerja efisiensi suatu bank karena mencakup keseluruhan tindakan operasional bank yaitu menyalurkan dana dari unit surplus ke unit defisit. Pendekatan ini menganalisis kinerja efisiensi bank syariah dengan mempertimbangkan input dan output dalam kegiatan operasionalnya.

Metode yang digunakan untuk mengestimasi skor efisiensi bank syariah ada dua yaitu parametrik dan non parametrik. Kedua metode berfungsi untuk mengestimasi frontier yang mewakili praktik terbaik dari sistem. Frontier hasil estimasi digunakan sebagai benchmark dari suatu bank yang dibandingkan dengan bank lainnya. Metode parametrik untuk mengestimasi nilai efisiensi adalah Least-Squares Econometric Production (LSEP) dan Stochastic Frontier Approach (SFA) sedangkan metode non parametrik yang dapat digunakan adalah Total Factor Productivity (TFP) dan Data Envelopment Analysis (DEA).

Pada penelitian ini estimasi skor efisiensi dilakukan dengan menggunakan kedua metode yaitu metode parametrik dan non parametrik, SFA dan DEA. Menurut Hassan (2006) analisis kinerja efisiensi perbankan dengan pendekatan parametrik dan non parametrik akan menghasilkan hasil yang lebih komprehensif karena kedua metode akan menghasilkan pengukuran efisiensi yang berbeda sehingga dapat saling melengkapi. Dengan penggunaan DEA dan SFA secara bersamaan, 
diharapkan penelitian ini dapat bermanfaat untuk dijadikan bahan evaluasi oleh pihak perbankan syariah.

DEA akan digunakan untuk mengestimasi nilai efisiensi teknis (TE), efisiensi teknis murni (PTE), dan skala efisiensi (ES) Efisiensi teknis merupakan kemampuan bank untuk menggunakan kombinasi input yang optimal untuk menghasilkan sejumlah output tertentu. TE dan PTE sebenarnya sama-sama merupakan efisiensi teknis hanya saja TE mengasumsikan bank beroperasi pada CRS (Constant Return to Scale) dan berada di pasar persaingan sempurna sedangkan PTE mengasumsikan bank tidak beroperasi di kondisi optimalnya (CRS). Skor TE dan PTE berkisar antara 0-1, semakin mendekati 1 (satu) maka bank dinilai semakin efisien. Pembagian skor TE oleh skor PTE akan menghasilkan ES. Jika ES bernilai 1 (satu), bank berada dalam kondisi Decreasing Return to Scale (DRTS) dan jika nilainya tidak sama dengan 1 (satu), bank beroperasi dalam kondisi Increasing Return to Scale (IRTS). Analisis mengenai pada skala apa bank syariah beroperasi bermanfaat bagi kebijakan yang tepat untuk mengembangkan perbankan syariah.

Selanjutnya, SFA akan digunakan untuk memperoleh nilai efisiensi keuntungan alternatif (APE). APE mengukur kemampuan bank untuk menghasilkan keuntungan maksimal pada jumlah output tertentu dibandingkan dengan kinerja terbaik bank lainnya dalam menghasilkan keuntungan (Kablan dan Yousfi 2013). Skor APE berkisar antara 0-1, semakin mendekati 1 (satu) maka bank dinilai semakin efisien dalam menciptakan keuntungan.

Setelah skor TE, PTE, ES, APE didapatkan, analisis dilanjutkan dengan model regresi Tobit yang diestimasi dengan metode MLE (Maximum Likelihood) untuk mengestimasi faktor-faktor yang berpengaruh terhadap tingkat efisiensi BUS. Dengan analisis ini diharapkan kebijakan peningkatan kinerja efisiensi BUS dapat difokuskan pada faktor-faktor yang terbukti berpengaruh secara signifikan.

\section{Metode Penelitian}

\subsection{Jenis dan Sumber Data}

Jenis data yang digunakan dalam penelitian ini merupakan data sekunder dalam bentuk panel data yaitu gabungan antara data kerat lintang Bank Umum Syariah dan data deret waktu kuartalan periode Juni 2012-Maret 2016 (Q2.2012-Q1.2016). Data pada penelitian ini diperoleh dari situs Bank Indonesia berupa Statistik Perbankan Syariah dan dari situs BUS berupa Laporan Keuangan Perbankan kuartalan.

\subsection{Metode Analisis dan Pengolahan Data}

Penelitian ini menggunakan metode analisis yang bersifat deskriptif dan kuantitatif. Analisis deskriptif dilakukan untuk eksplorasi, klarifikasi mengenai suatu fenomena sosial dengan cara mendeskripsikan sejumlah variabel yang berhubungan dengan permasalahan dan unit penelitian. Dalam metode analisis deskriptif disajikan gambar/grafik dalam bentuk plot data mengenai kondisi BUS. Melalui gambaran umum ini diharapkan dapat menguatkan analisis ekonometrika untuk menjawab tujuan penelitian ini.

Analisis kuantitatif bersifat objektif, dilakukan dengan menjabarkan fenomena sosial ke beberapa komponen masalah, variabel, dan indikator. Analisis kuantitatif digunakan dalam penelitian ini melalui Data Envelopment Analyst (DEA), Stochastic Frontier Analysis (SFA), dan tobit. DEA dan SFA digunakan untuk menghitung skor efisiensi BUS. Tobit digunakan untuk menganalisis faktorfaktor yang berpengaruh terhadap kinerja efisiensi BUS dengan estimasi metode MLE (Maximum Likelihood). Perangkat lunak yang digunakan dalam analisis ini adalah Microsoft Excel 2013, Frontier Analyst 4.1, Front41, dan Eviews 9. 


\subsubsection{Data Envelopment Analysis (DEA)}

Data Envelopment Analysis (DEA) digunakan untuk mengestimasi skor efisiensi teknis, efisiensi teknis murni, dan skala efisiensi yang berkisar antara 0-1 menggunakan pendekatan intermediasi dengan orientasi input. Orientasi input digunakan karena menurut Coelli (1998) bank akan lebih mudah untuk mengontrol jumlah input yang digunakan daripada jumlah output yang dihasilkan. Terdapat 3 (tiga) input dan output dalam estimasi skor efisiensi teknis, efisiensi teknis murni, dan skala efisiensi yang dijelaskan pada Tabel 2.

Tabel 2 Input-output model DEA

\begin{tabular}{|c|c|c|}
\hline Variabel & Definisi & Rujukan \\
\hline \multicolumn{3}{|l|}{ Input } \\
\hline Biaya tenaga kerja & Biaya tenaga kerja, biaya personalia & $\begin{array}{l}\text { Rahman dan Rosman } \\
\text { (2013) }\end{array}$ \\
\hline Biaya aset tetap & Biaya operasional & $\begin{array}{l}\text { Rahman dan Rosman } \\
\text { (2013) }\end{array}$ \\
\hline Dana pihak ketiga & Dana simpanan wadiah & $\begin{array}{l}\text { Rahman dan Rosman } \\
\text { (2013) }\end{array}$ \\
\hline \multicolumn{3}{|l|}{ Output } \\
\hline Pembiayaan & $\begin{array}{l}\text { Murabahah, musyarakah, } \\
\text { mudharabah, istishna, salam }\end{array}$ & $\begin{array}{l}\text { Rahman dan Rosman } \\
\text { (2013) }\end{array}$ \\
\hline $\begin{array}{l}\text { Pendapatan } \\
\text { operasional }\end{array}$ & Pendapatan penyaluran dana & $\begin{array}{l}\text { Rahman dan Rosman } \\
\text { (2013) }\end{array}$ \\
\hline Pendapatan lainnya & Pendapatan operasional lainnya & $\begin{array}{l}\text { Rahman dan Rosman } \\
\text { (2013) }\end{array}$ \\
\hline
\end{tabular}

\subsubsection{Stochastic Frontier Approach (SFA)}

Stochastic Frontier Approach (SFA) merupakan metode parametrik yang digunakan untuk mengestimasi skor efisiensi keuntungan alternatif. Model yang digunakan pada penelitian ini mengacu pada Mghaieth dan Mehdi (2014), yaitu:

$\ln \left(\pi_{\mathrm{it}}+\mathrm{a}\right)=\ln \mathrm{f}\left(\mathrm{P}_{\mathrm{it}}, \mathrm{Y}_{\mathrm{it}}\right)+\ln \varepsilon_{\mathrm{it}}$

Keterangan:

$\pi_{\mathrm{it}} \quad$ : Total keuntungan bank ke-i pada periode ke-t

a : Konstanta

$\mathrm{P}_{\text {it }} \quad$ : Harga input ke-i pada periode ke-t

$\mathrm{Y}_{\text {it }} \quad$ : Output bank ke-i pada periode ke-t

$\varepsilon_{\text {it }} \quad:$ galat $\left(u_{\text {it }}+e_{\text {it }}\right)$

Deskripsi variabel pada model SFA dijelaskan oleh Tabel 3.

Tabel 3 Deskripsi variabel model SFA

\begin{tabular}{lll}
\hline \multicolumn{1}{c}{ Variabel } & \multicolumn{1}{c}{ Notasi } & \multicolumn{1}{c}{ Definisi } \\
\hline Variabel & $\Pi$ : total keuntungan & Pendapatan - total biaya \\
dependen & $\mathrm{P}_{1}$ : biaya tenaga kerja & Biaya tenaga kerja \\
Harga input & $\mathrm{P}_{2}$ : biaya dana pihak ketiga & Biaya bagi hasil \\
& $\mathrm{P}_{3}$ : biaya aset tetap & Biaya operasional lainnya \\
& $\mathrm{Y}_{1}:$ total pembiayaan & $\begin{array}{l}\text { Murabahah, musyarakah, } \\
\text { mudharabah, istishna, salam }\end{array}$ \\
& & Pendapatan dari investasi \\
& $\mathrm{Y}_{2}:$ pendapatan operasional lainnya & yang dilakukan bank \\
\hline
\end{tabular}




\subsubsection{Tobit}

Tahapan pertama yang dilakukan dalam penelitian ini adalah estimasi skor efisiensi dengan menggunakan metode DEA dan SFA. Skor efisiensi yang dihasilkan adalah skor efisiensi teknis, skor efisiensi teknis murni, skala efisiensi dengan DEA dan skor efisiensi keuntungan alternatif dengan SFA. Pada tahapan kedua dalam penelitian ini akan dilakukan analisis faktor-faktor yang berpengaruh terhadap skor efisiensi yang telah dihasilkan pada tahap pertama.

Tobit mengasumsikan bahwa variabel-variabel independen pada model tidak memiliki batasan nilai (non-censured) sedangkan variabel dependen pada model memiliki batasan nilai (censured). Nilai skor efisiensi yang berkisar antara $0-1$ membuat model Tobit merupakan metode yang tepat untuk mengestimasi koefisien regresi dalam analisis faktor-faktor yang memengaruhi kinerja efisiensi sebuah BUS.

Terdapat 4 (empat) model yang diestimasi pada penelitian ini. Model I bertujuan mengestimasi faktor-faktor yang berpengaruh terhadap efisiensi teknis (TE) BUS sedangkan model II bertujuan mengestimasi faktor-faktor yang berpengaruh terhadap efisiensi teknis murni (PTE) BUS. Model selanjutnya yaitu Model III digunakan untuk mengestimasi faktor-faktor yang berpengaruh terhadap skala efisiensi (ES) BUS dan Model IV digunakan untuk mengestimasi faktor-faktor yang berperngaruh terhadap efisiensi keuntungan alternatif (APE) BUS. Variabel independen yang digunakan dalam keempat model sama, yaitu total pembiayaan, modal inti, dana simpanan wadiah, biaya operasional, total aset, ROE, dan CAR.

Model regresi tobit terbaik yang dihasilkan dalam penelitian ini secara umum dirumuskan sebagai berikut:

Model I

$$
\begin{aligned}
\mathrm{TE}_{\mathrm{it}}= & \mathrm{b}_{0}+\mathrm{b}_{1} \operatorname{Ln} \mathrm{X}_{1 \mathrm{it}}+\mathrm{b}_{2} \operatorname{Ln} \mathrm{X}_{2 \mathrm{it}}+\mathrm{b}_{3} \operatorname{Ln} \mathrm{X}_{3 \mathrm{it}}+\mathrm{b}_{4} \operatorname{Ln} \mathrm{X}_{4 \mathrm{it}}+\mathrm{b}_{5} \operatorname{Ln} \mathrm{X}_{5 \mathrm{it}}+ \\
& \mathrm{b}_{6} \mathrm{X}_{6 \mathrm{it}}+\mathrm{b}_{7} \mathrm{X}_{7 \mathrm{it}}+\mathrm{e}_{\mathrm{it}}
\end{aligned}
$$

Model II

$$
\begin{aligned}
\text { PTE }_{\text {it }}= & b_{0}+b_{1} \operatorname{Ln} X_{1 i t}+b_{2} \operatorname{Ln} X_{2 i t}+b_{3} \operatorname{Ln} X_{3 i t}+b_{4} \operatorname{Ln} X_{4 i t}+b_{5} \operatorname{Ln} X_{5 i t}+ \\
& b_{6} X_{6 i t}+b_{7} X_{7 i t}+e_{i t}
\end{aligned}
$$

Model III

$$
\begin{aligned}
\mathrm{ES}_{\mathrm{it}}= & \mathrm{b}_{0}+\mathrm{b}_{1} \operatorname{Ln} \mathrm{X}_{1 \mathrm{it}}+\mathrm{b}_{2} \operatorname{Ln} \mathrm{X}_{2 \mathrm{it}}+\mathrm{b}_{3} \operatorname{Ln} \mathrm{X}_{3 \mathrm{it}}+\mathrm{b}_{4} \operatorname{Ln} \mathrm{X}_{4 \mathrm{it}}+\mathrm{b}_{5} \operatorname{Ln} \mathrm{X}_{5 \mathrm{it}}+ \\
& \mathrm{b}_{6} \mathrm{X}_{6 \mathrm{it}}+\mathrm{b}_{7} \mathrm{X}_{7 \mathrm{it}}+\mathrm{e}_{\mathrm{it}}
\end{aligned}
$$

Model IV

$$
\begin{aligned}
\mathrm{APE}_{\mathrm{it}}= & \mathrm{b}_{0}+\mathrm{b}_{1} \operatorname{Ln} \mathrm{X}_{1 \mathrm{it}}+\mathrm{b}_{2} \operatorname{Ln} \mathrm{X}_{2 \mathrm{it}}+\mathrm{b}_{3} \operatorname{Ln} \mathrm{X}_{3 \mathrm{it}}+\mathrm{b}_{4} \operatorname{Ln} \mathrm{X}_{4 \mathrm{it}}+\mathrm{b}_{5} \operatorname{Ln} \mathrm{X}_{5 \mathrm{it}}+ \\
& \mathrm{b}_{6} \mathrm{X}_{6 \mathrm{it}}+\mathrm{b}_{7} \mathrm{X}_{7 \mathrm{it}}+\mathrm{e}_{\mathrm{it}}
\end{aligned}
$$

Keterangan:

$\mathrm{TE}_{\text {it }} \quad$ : Skor efisiensi teknis BUS ke-i pada periode ke-t

$\mathrm{PTE}_{i t}$ : Skor efisiensi teknis murni BUS ke-i pada periode ke-t

$\mathrm{ES}_{\text {it }} \quad$ : Skor skala efisiensi BUS ke-i pada periode ke-t

$\mathrm{APE}_{\mathrm{it}} \quad$ : Skor efisiensi keuntungan alternatif BUS ke-i pada periode ke-t

$\mathrm{b}_{0} \quad$ : intersep

$b_{i} \quad$ : koefisien variabel ke-i

$\mathrm{X}_{1 \mathrm{it}} \quad$ : Total pembiayaan BUS ke-i pada periode ke-t (dalam \%)

$\mathrm{X}_{2 \text { it }} \quad$ : Modal inti BUS ke-i pada periode ke-t (dalam \%)

$\mathrm{X}_{3 \mathrm{it}}$ : Dana simpanan wadiah BUS ke-i pada periode ke-t (dalam \%)

$\mathrm{X}_{4 \mathrm{it}} \quad$ : Biaya operasional ke-i pada periode ke-t (dalam \%)

$\mathrm{X}_{5 \mathrm{it}} \quad$ : Total aset BUS ke-i pada periode ke-t (dalam \%)

$\mathrm{X}_{6 \mathrm{it}}$ : Return on Equity (ROE) ke-i pada periode ke-t

Jurnal Al-Muzara'ah Vol.4, No.1, 2016

(ISSN p: 2337-6333; e: 2355-4363) 
$\mathrm{X}_{7 \mathrm{it}} \quad$ : Capital Adequancy Ratio (CAR) ke-i pada periode ke-t

$\mathrm{e}_{\mathrm{it}} \quad$ : galat

\subsubsection{Pengujian parameter hasil estimasi model regresi tobit}

Terdapat dua uji yang digunakan pada parameter hasil estimasi model regresi tobit yaitu:

\section{Likelihood Ratio test}

Likelihood Ratio test dalam model tobit dilakukan untuk mengetahui apakah variabel bebas dalam model bersama-sama berpengaruh terhadap variabel tidak bebas secara nyata. Hipotesis Likelihood Ratio test untuk adalah:

$\mathrm{H}_{0}: \mathrm{b}_{\mathrm{o}}=\mathrm{b}_{1}=\mathrm{b}_{2}=\mathrm{b}_{3}=\mathrm{b}_{4}=\mathrm{b}_{5}=\mathrm{b}_{6}=0$

$\mathrm{H}_{1}$ : Minimal ada satu $b_{\mathrm{i}}$ yag tidak sama dengan nol

Jika nilai Likelihood Ratio yang didapatkan dari hasil estimasi > taraf nyata maka tolak $\mathrm{H}_{0}$ yang artinya variabel-variabel bebas dalam model secara bersama-sama berpengaruh nyata terhadap variabel tidak bebas. Jika nilai probabilitas Likelihood Ratio yang didapatkan < taraf nyata maka tidak tolak $\mathrm{H}_{0}$ yang artinya variabel-variabel bebas dalam model secara bersama-sama berpengaruh tidak nyata terhadap variabel bebasnya.

\section{Wald test}

Wald test dalam model tobit dilakukan untuk mengetahui suatu variabel bebas berpengaruh secara signifikan atau tidak signifikan terhadap variabel tidak bebas. Hipotesis untuk wald test adalah:

$\mathrm{H}_{0}$ : variabel bebas tidak signifikan

$\mathrm{H}_{1}$ : variabel bebas signifikan

Jika nilai probabilitas t-statistik suatu variabel yang didapatkan dari hasil estimasi < taraf nyata maka tolak $\mathrm{H}_{0}$ yang artinya variabel bebas tersebut berpengaruh secara signifikan terhadap variabel tidak bebas dalam model. Sebaliknya, jika nilai probabilitas t-statistik suatu variabel > taraf nyata maka tidak tolak $\mathrm{H}_{0}$ yang artinya variabel bebas tersebut tidak berpengaruh secara signifikan terhadap variabel tidak bebas dalam model.

Tabel 4 Definisi operasional variabel independen pada model tobit

\begin{tabular}{lll}
\hline Variabel & Deskripsi & Rujukan \\
\hline
\end{tabular}

Total pembiayaan

Pembiayaan yang disalurkan BUS yaitu mudharabah, musyarakah, ishtisna, Hassan (2006) salam, murabahah

Modal inti

Dana simpanan Dana pihak ketiga dengan akad wadiah wadiah (titipan)

Widiarti et al. (2015)

Biaya operasional

Biaya yang dikeluarkan BUS untuk

Mghaieth dan Mehdi (2014) kegiatan operasional

Hassan (2006), Mghaieth

Aset Total aset yang dimiliki BUS dan Mehdi (2014), Rahman dan Rosman (2013), viverita dan arif (2011), Widiarti et 


\begin{tabular}{|c|c|c|}
\hline Variabel & Deskripsi & Rujukan \\
\hline & & $\begin{array}{l}\text { al. (2015), Firdaus dan } \\
\text { Hosen (2013) }\end{array}$ \\
\hline ROE & $\begin{array}{l}\text { Rasio total keuntungan BUS sebelum } \\
\text { pajak dengan total ekuitas }\end{array}$ & $\begin{array}{l}\text { Hassan (2006), Firdaus dan } \\
\text { Hosen (2013), Guphta et al. } \\
2008\end{array}$ \\
\hline CAR & Rasio kecukupan modal & $\begin{array}{l}\text { Mghaieth dan Mehdi (2014), } \\
\text { Widiarti et al. (2015), } \\
\text { Firdaus dan Hosen (2013) }\end{array}$ \\
\hline
\end{tabular}

\subsection{Sampel Penelitian}

Penelitian ini menggunakan sampel penelitian sebanyak sepuluh Bank Umum Syariah di Indonesia yang telah beroperasi dari tahun 2012 sampai dengan saat ini. Data yang digunakan merupakan publikasi laporan triwulan tiap bank yang didapatkan dari situs resmi tiap bank periode Q2.2012 Q1.2016.

Tabel 5 Daftar sampel penelitian

\begin{tabular}{cll}
\hline No & \multicolumn{1}{c}{ Bank Umum Syariah } & \multicolumn{1}{c}{ Situs } \\
\hline 1 & Bank Syariah Mandiri & $\mathrm{http} / / /$ syariahmandiri.co.id \\
2 & Bank Muamalat Indonesia & $\mathrm{http} / / /$ muamalatindonesia.co.id \\
3 & Bank Rakyat Indonesia Syariah & $\mathrm{http} / / / \mathrm{brisyariah.co.id}$ \\
4 & Bank Negara Indonesia Syariah & $\mathrm{http} / / / \mathrm{bnisyariah.co.id}$ \\
5 & Bank Panin Syariah & $\mathrm{http} / / /$ paninbanksyariah.co.id \\
6 & Bank Bukopin Syariah & $\mathrm{http} / / /$ syariahbukopin.co.id \\
7 & Bank Mega Syariah & $\mathrm{http} / / /$ megasyariah.co.id \\
8 & Bank Central Asia Syariah & $\mathrm{http} / / / \mathrm{bcasyariah.co.id}$ \\
9 & Maybank Syariah & $\mathrm{http} / / /$ maybanksyariah.co.id \\
10 & Bank Victoria Syariah & $\mathrm{http} / / /$ victoriasyariah.co.id \\
\hline
\end{tabular}

\section{Hasil dan Pembahasan}

\subsection{Efisiensi Bank Umum Syariah di Indonesia}

Hasil estimasi skor efisiensi teknis (TE), efisiensi teknis murni (PTE), skala efisiensi (ES) dengan metode DEA dan skor efisiensi keuntungan alternatif (APE) dengan metode SFA ditunjukkan oleh Tabel 6. Seperti yang telah dijelaskan sebelumnya, skor efisiensi berkisar antara $0-1$, semakin mendekati skor 0 (nol) menandakan semakin efisien BUS dalam kegiatan operasionalnya sebagai lembaga intermediasi. Sebaliknya, semakin mendekati skor 1 (satu) menunjukkan bahwa BUS semakin efisien dalam kegiatan operasionalnya dan semakin optimal menjalankan fungsinya sebagai lembaga intermediasi (Firdaus dan Hosen 2013).

Tabel 6 menunjukan efisiensi BUS di Indonesia periode Q2.2012 - Q1.2016. Secara umum, BUS di Indonesia belum beroperasi secara efisien. Hal ini terbukti dari skor rata-rata efisiensi belum mencapai skor sempurna yaitu 1 (satu) kecuali pada skor efisiensi murni (PTE) kuartal Q4.2014, Q4.2015, dan Q1.2016. Dari nilai TE dan PTE dibuktikan bahwa BUS belum dapat beroperasi menggunakan kombinasi input yang optimal untuk memproduksi outputnya. Hasil ini sesuai dengan hipotesis penelitian dan hasil beberapa penelitian sebelumnya yaitu Praktiko dan Sugianto (2011), Viverita Ariff (2011), serta Firdaus dan Hosen (2013). 
Nilai skala efisiensi didapatkan dari pembagian skor TE oleh skor PTE. Dari nilai skala efisiensi secara keseluruhan dapat disimpulkan bahwa saat ini BUS beroperasi pada kondisi Increasing Return to Scale. Peningkatan input akan menghasilkan peningkatan output yang lebih besar dari proporsi peningkatan inputnya. Hal ini sesuai dengan keadaan industri perbankan syariah di Indonesia yang saat ini masih dalam tahap infant.

Skor efisiensi keuntungan alternatif menunjukan bahwa BUS di Indonesia belum mampu menghasilkan keuntungan maksimum dengan sejumlah input tertentu. Hal ini sejalan dengan ROA BUS yang masih relatif rendah dan ROA mencerminkan profitabilitas BUS masih rendah. Menurut Mahmoedin (2004) salah satu faktor yang memengaruhi profitabilitas perbankan adalah kualitas pinjaman. Di Indonesia, pembiayaan yang disalurkan umumnya bergerak di sektor kecil sehingga keuntungan yang dihasilkan pun tidak besar. Implikasinya adalah ROA yang dicapai rendah.

Tabel 6 Efisiensi BUS periode 2012-2016

\begin{tabular}{|c|c|c|c|c|c|}
\hline & & TE & PTE & ES & APE \\
\hline \multirow[t]{3}{*}{2012} & Kuartal II & 0.89 & 0.98 & 0.91 & 0.76 \\
\hline & & & 0.99 & 0.85 & 0.79 \\
\hline & & 0.95 & 0.99 & 0.95 & 0.99 \\
\hline \multirow[t]{4}{*}{2013} & & 0.74 & 0.96 & 0.77 & 0.99 \\
\hline & & 0.84 & 0.98 & 0.85 & 0.86 \\
\hline & & 85 & 0.99 & 0.86 & 0.86 \\
\hline & & 91 & 0.99 & 0.92 & 0.88 \\
\hline \multirow[t]{4}{*}{2014} & & 0.84 & 0.99 & 0.85 & 0.87 \\
\hline & & 0.81 & 0.98 & 0.83 & 0.78 \\
\hline & & 0.76 & 0.98 & 0.77 & 0.83 \\
\hline & & 0.79 & 1.00 & 0.80 & 0.77 \\
\hline \multirow[t]{4}{*}{2015} & & 0.76 & 0.97 & 0.78 & 0.82 \\
\hline & & 0.91 & 0.96 & 0.94 & 0.99 \\
\hline & & 0.86 & 0.99 & 0.87 & 0.99 \\
\hline & & 0.86 & 1.00 & 0.86 & 0.75 \\
\hline 2016 & Kuartal I & 0.90 & 1.00 & 0.90 & 0.81 \\
\hline
\end{tabular}

Tren pergerakan skor efisiensi TE, PTE, ES, dan APE pada periode Q2.2012-Q1.2016 ditunjukan oleh Gambar 10. Skor efisiensi murni merupakan skor efisiensi dengan fluktuasi yang paling rendah atau dengan kata lain BUS memiliki stabilitas yang cukup baik dalam meminimalkan jumlah input untuk menghasilkan sejumlah output tertentu dengan asumsi VRS. Efisiensi lainnya yaitu efisiensi teknis, skala efisiensi, dan efisiensi keuntungan alternatif relatif lebih berfuktuasi. Pergerakan efisiensi teknis sejalan dengan skala efisiensi. Kondisi ini disebabkan oleh perhitungan skala efisiensi diperoleh dari nilai efisiensi teknis.

Efisiensi keuntungan alternatif pun berfluktuasi dari Q2.2012 sampai Q1.2016. Peningkatan skor efisiensi keuntungan alternatif terjadi periode Q3.2012 ke Q4.2012 kemudian stabil sampai Q1.2013 dan kembali menurun di kuartal selanjutnya. Pola ini terulang kembali pada Q1.2015. Kemampuan mempertahankan efisiensi keuntungan alternatif dengan skor optimal hanya dapat terjadi di satu kuartal kemudian menurun pada kuartal berikutnya. Hal ini disebabkan banyak faktor diantaranya beban operasional yang terus berfluktuasi, begitu juga dengan pendapatan operasional. 


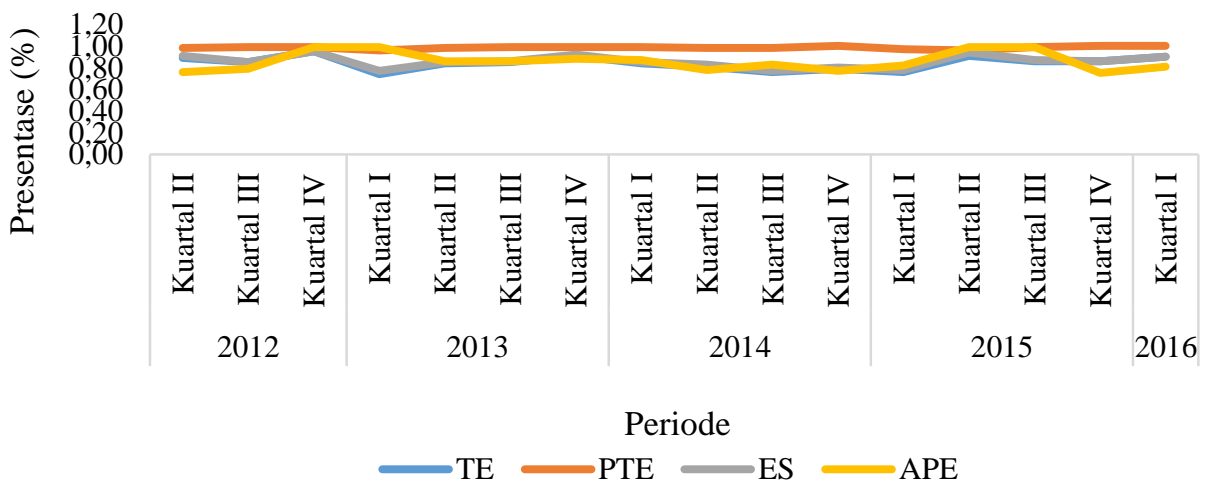

Sumber: output DEA dan SFA (2016, diolah)

Gambar 1 Tren pergerakan skor efisiensi BUS periode 2012-2016

\subsubsection{Faktor-faktor yang berpengaruh terhadap kinerja efisiensi BUS}

Faktor-faktor yang berpengaruh terhadap kinerja efisiensi BUS dianalisis melalui model regresi Tobit yang diestimasi dengan metode Maximum Likelihood (MLE). Model pada tabel 8 merupakan model terbaik yang telah lulus kriteria pada Likelihood Ratio test dengan nilai Likelihood Ratio seesar 14.1536, lebih besar dari alpha 5\%. Model juga telah memenuhi kriteria pada Wald test dengan semua variabel independen memiliki nilai probabilitas 0.0000 , kurang dari alpha $5 \%$.

Tabel 7 menunjukkan hasil estimasi model Tobit. Pada Model I terbukti bahwa pembiayaan, ROE, dan CAR berpengaruh positif dan signifikan terhadap efisiensi teknis BUS. Hasil ini sejalan dengan hipotesis penelitian. Pembiayaan merupakan output yang dihasilkan BUS. Semakin besar pembiayaan yang disalurkan BUS, semakin optimal BUS menjalankan fungsinya sebagai lembaga intermediasi. Hal yang sama juga ditemukan pada penelitian yang dilakukan Widiarti et al. (2015). ROE mewakili tingkat profitabilitas suatu BUS. BUS yang dapat menghasilkan keuntungan yang lebih besar dapat diindikasikan sebaga BUS yang efisien. Hasil yang sama juga ditemukan oleh Firdaus dan Hosen (2013) serta Guphta et al. (2008). CAR merupakan rasio kecukupan modal, saat BUS memiliki modal yang cukup, Ia akan lebih mampu untuk menghadapi risiko di masa mendatang sehingga kinerjanya akan lebih efisien. Hasil ini ditemukan pula oleh Subandi dan Ghozali (2013) serta Widiarti et al. (2015).

Sebaliknya, simpanan wadiah berpengaruh negatif dan signifikan terhadap efisiensi teknis BUS. Hasil ini berlawanan dengan hipotesis penelitian. Kondisi yang sama juga terjadi di estimasi model II dan model III. Pembiayaan, ROE, dan CAR berpengaruh positif dan signifikan terhadap skala efisiensi sedangkan simpanan wadiah berpengaruh negatif dan signifikan terhadap skala efisiensi. Hal ini dapat disebabkan oleh beban biaya bonus yang dikeluarkan oleh BUS untuk nasabah yang menitipkan dananya. Semakin banyak simpaan wadiah yang diterima BUS, semakin besar beban biaya bonus sehingga akan menyebabkan menurunnya efisiensi teknis, efisiensi teknis murni, skala efisiensi, dan efisiensi keuntungan alternatif.

Tabel 7 Faktor-faktor yang berpengaruh terhadap kinerja efisiensi BUS

\begin{tabular}{lcccc}
\hline \multirow{3}{*}{ Variabel } & Model I & Model II & Model III & Model IV \\
& TE & PTE & ES & APE \\
\cline { 2 - 5 } & \multicolumn{4}{c}{ Koefisien (probabilitas) } \\
\hline \multirow{2}{*}{ Ln pembiayaan } & 0.488 & 0.007 & 0.044 & 0.039 \\
\multirow{2}{*}{ Ln modal } & $\left(0.000^{*}\right)$ & $\left(0.019^{* *}\right)$ & $\left(0.000^{*}\right)$ & $\left(0.000^{*}\right)$ \\
& $-0.576(0.271)$ & -0.010 & -0.539 & 0.005 \\
& & $(0.598)$ & $(0.294)$ & $(0.917)$ \\
\hline
\end{tabular}




\begin{tabular}{lcccc}
\hline \multirow{4}{*}{ Variabel } & Model I & Model II & Model III & Model IV \\
& TE & PTE & ES & APE \\
\cline { 2 - 5 } & & Koefisien (probabilitas) & \\
\hline \multirow{2}{*}{ Ln simpanan wadiah } & -0.403 & -0.011 & -0.031 & 0.007 \\
& $\left(0.016^{* *}\right)$ & $\left(0.065^{* * *}\right)$ & $\left(0.062^{* * *}\right)$ & $(0.669)$ \\
Ln biaya operasional & $-0.019(0.116)$ & $0.004(0.327)$ & 0.015 & -0.027 \\
& & & $(0.197)$ & $\left(0.040^{*}\right)$ \\
Ln aset & $-0.036(0.387)$ & $0.009(0.529)$ & -0.042 & -0.001 \\
& & & $(0.310)$ & $(0.977)$ \\
ROE & 0.001 & $0.002(0.278)$ & 0.001 & 0.008 \\
\multirow{2}{*}{ CAR } & $\left(0.033^{* *}\right)$ & & $\left(0.061^{* * *}\right)$ & $(0.255)$ \\
& 0.005 & $0.007(0.399)$ & 0.005 & 0.006 \\
& $\left(0.020^{* *}\right)$ & & $\left(0.024^{* *}\right)$ & $(0.785)$ \\
\hline
\end{tabular}

Keterangan:

$*, * *, * * *$ signifikan pada taraf nyata $1 \%, 5 \%, 10 \%$

Sumber: Output Tobit (2016, diolah)

\section{Kesimpulan dan Saran}

\subsection{Kesimpulan}

Berdasarkan hasil penelitian maka simpulan yang diperoleh sebagai berikut:

1. BUS di Indonesia belum beroperasi secara efisien berdasarkan skor efisiensi teknis, skor efisiensi teknis murni, dan skala efisiensi yang diperoleh dengan metode DEA.

2. BUS di Indonesia belum dapat mengoptimalkan keuntungannya berdasarkan skor efisiensi keuntungan alternatif yang diperoleh degan metode SFA.

3. Pembiayaan, ROE, dan CAR berpengaruh positif dan signifikan sedangkan simpanan wadiah berpengaruh negatif dan signifikan terhadap efisiensi teknis dan skala efisiensi BUS. Pembiayaan berpengaruh positif dan signifikan sedangkan simpanan wadiah berpengaruh negatif dan signifikan terhadap efisiensi teknis murni. Efisiensi keuntungan alternatif dipengaruhi secara signifikan oleh pembiayaan dengan tanda positif dan biaya operasional dengan tanda negatif.

\subsection{Saran}

Berdasarkan simpulan di atas maka manajemen BUS perlu memperhatikan faktor internal yang berpengaruh signifikan terhadap efisiensi yaitu pembiayaan, dana simpanan wadiah, ROE, CAR, dan biaya operasional dengan melakukan hal-hal antara lain:

1. Melakukan pengelolaan pembiayaan dengan baik sehingga pembiayaan yang disalurkan optimal. Hal-hal yang dapat menjadi perhatian khusus adalah manajemen pemasaran, penargetan pembiayaan tidak hanya di sektor-sektor kecil, peningkatan kualitas SDM di bidang pembiayaan agar pembiayaan yang disalurkan merupakan pembiayaan yang berkualitas, memberikan pembiayaan berdasarkan prinsip kehati-hatian, melakukan restrkturisasi terhadap pembiayaan yang berkualitas namun menurun kualitasnya, tidak mmeberikan pembiayaan ke sektor ekonomi yang tidak memiliki prospek dengan baik.

2. Meningkatkan kemampuan dalam menciptakan keuntungan sehingga ini dapat menjadi daya tarik tersendiri bagi masyarakat untuk menyalurkan dananya melalui BUS.

3. Melakukan peninjauan terhadap biaya operasional yang dikeluarkan.

Dengan mempertimbangkan bahwapenelitian ini hanya melibatkan sepuluh (10) BUS di Indonesia dengan faktor-faktor internalnya maka beberapa saran untuk penelitian selanjutnya antara lain:

1. Penambahan variabel makroekonomi dalam menganalisis kinerja efisiensi BUS seperti tingkat inflasi, GDP, nilai tukar, dan pertumbuhan ekonomi. 
2. Menganalisis perbandingan kinerja efisiensi BUS di negara-negara yang memiliki karakter cukup dekat dengan Indonesia misalnya negara-egara di Asia Tenggara.

\section{Daftar Pustaka}

[BI] Bank Indonesia. 2009 - 2016. Statistik Perbankan Syariah [internet]. [diunduh 2016 Juli 16]. Tersedia pada: http://www.bi.go.id.

Coelli et al. 1998. An Introduction to Efficiency and Productivity Analysisi $2^{\text {nd }}$ Ed. New York (US): Springer.

Firdaus MF, Hosen MN. 2013. Efisiensi Bank Umum Syariah Menggunakan Pendekatan Two Stage Data Envelopment Analysis. Bank Indonesia: Buletin Ekonomi Moneter dan Perbankan Vol.11 (2).

Hassan MK. 2006. The X-Efficiency in Islamic Banks. Islamic Economic Study Vol.13 (2): 49-78.

Havidz, Setiawan. 2015. A Comparative Study of Efficiency Between Conventional and Islamic Banking in Indonesia. Asian Economic and Financial Review Vol.5 (5): 790-804.

Irfan M, Majeed Y, Zaman K. 2014. The Performance and Efficiency of Islamic Banking in South Asian Country. Economia Seria Management. Vol.17 (2): 223 - 236.

Kablan, Yousfi. 2013. What Drives Efficiency of Islamic Banks Among Regions? The Journal of Applied Business Research Vol.29 (5): 1411-1420.

Mghaieth A, Mehdi IKE. 2014. The Determinants of Cost/Profit Efficiency of Islamic Banks Before, During, and After Crisis of 2007-2008 Using SFA Approach. Working Paper: Lpag Business School.

Mohamad S, Hassan T, Bader MKI. 2009. Efficiency of Conventional versus Islamic Banks: International Evidence using the Stochastic Frontier Approach (SFA). Journal of Islamic Economics, Banking, and Finance.

Mokhtar et al. 2006. Efficiency of Islamic Banking in Malaysia: A Stochastic Frontier Approach. Journal of Economic Cooperation Vol.27 (2): 37-70.

Praktiko, Sugiarto. 2011. Kinerja Efisiensi Bank Syariah Sebelum dan Sesudah Krisis Global berdasarkan Data Envelopment Analysis (DEA). Jurnal Ekonomi Bisnis Vol.16 (2).

Rahman ARA, Rosman R. 2013. Efficiency of Islamic Banks: A Comparative Analysis of MENA and Asian Countries. Journal of Economic Cooperatio and Development Vol.34 (1): 63-92.

Subandi, Ghozali I. 2013. Determinan Efisiensi dan Dampaknya terhadap Kinerja Profitabilitas Industri Perbankan di Indonesia. Jurnal Keuangan dan Perbankan Vol.17(1): 123-135.

Viverita, Ariff M. 2011. Efficiency Measurement and Determinants of Indonesian Bank Efficiency. Widiarti AW, Siregar H, Andati T. 2015. The Determinants of Bank`s Efficiency in Indonesia. Bank Indonesia: Buletin Ekonomi Moneter dan Perbankan Vol.18 (2): 129-156. 